\title{
PENGARUH DAYA TARIK WISATA DAN AKSESIBILITAS TERHADAP TINGKAT KUNJUNGAN WISATA KE DESA BOTI KABUPATEN TIMOR TENGAH SELATAN
}

\author{
Melky Kabu,SE.,M.Par \\ Jurusan Pariwisata, Politeknik Negeri Kupang \\ JI. Adisucipto Kampus Penfui-Kupang NTT \\ E-mail: melky_kabu@yahoo.co.id
}

\begin{abstract}
Abstrak
Studi dalam penelitian ini mengenai pengaruh daya tarik wisata dan aksesibilitas terhadpa tingkat kunjungan wisata ke Desa Boti. Masalah yang diangkat dalam penelitian ini yaitu : (1) apakah daya tarik wisata mempengaruhi tingkat kunjungan wisata ke Desa Boti, (2) apakah aksesibilitas mempengaruhi tingkat kunjungan wisata ke desa Boti.

Penelitian ini menggunakan pendekatan analisis deskriptif kualitatif, data-data yang dikumpulkan dalam penelitian ini dikumpulkan dalam kondisi yang asli dan alamiah. Instrumen kunci dalam peneltian ini adalah peneliti sebagai alat penelitian, artinya peneliti sebagai alat utama pengumpul data dengan metode observasi, menyebarkan lembar pertanyaan dan melakukan wawancara. Pengumpulan sampel dengan cara purposive sampling. Keputusan dan hasil dari penelitian dikaitkan serta dianalisis secara descriptif, dengan mentrasnformasi datamentah ke dalam bentuk data yang mudah dimengerti dan ditafsirkan, termasuk menyusun, memanipulasi, dan menyajikan supaya menajdi suatu informasi. Kemudian menginterpretasi data sebagai kajian pokok.

Hasil yang didapat dalam penelitian ini adalah : pengaruh daya tarik wisata dalam hal ini daya tarik kebudayaan dengan presentasi 95\% mempengaruhi tingkat kunjungan wisata ke desa boti, sedangakan pengaruh aksesibilitas dengan presentasi 90\% mengatakan buruk.

Dari hasil penelitian ini didapatkan saran-saran untuk menciptakan pariwisata berkelanjutan di desa Boti (1) perlu ada perda untuk desa Boti (2) memperhatikan dan memperbaiki kondisi jalan ke desa Boti (3) diperhatikan sarana transportasi ke Desa Boti.
\end{abstract}

Kata Kunci : Daya tarik wisata, aksesibilitas, suku Boti

\section{PENDAHULUAN}

\section{Latar Belakang Masalah}

Naisbitt $(1994 ; 109)$ memprediksikan bahwa pariwisata akan menjadi penghasil terbesar dan terkuat dalam pembiayaan ekonomi global [1]. Pariwisata akan menyerap 204 juta tenaga kerja, penghasil 10,2 persen produk nasional bruto dunia sehingga berpotensi memberi kontribusi pajak sebesar \$ 655 milyar. Demikian juga dalam World Tourism Organization sebagaimana ditegaskan Susanto dkk; (2003:211), melontarkan estimasi optimistik dalam WTO'S Tourism 2020 Vision, yang memperkirakan jumlah kunjungan wisatawan internasional di seluruh dunia akan mencapai 1.006,4 juta pada tahun 2010 dan 1.561 juta pada tahun 2020. Secara total, tingkat kunjungan wisatawan diperkirakan akan bertumbuh 4,1\% pertahun. Untuk wilayah Asia Timur dan Pasifik diperkirakan dapat mencapai pertumbuhan $6,5 \%$.

Sehingga menurut Susanto dkk, (2003:227-228) sektor pariwisata mempunyai potensi sebagai lokomotif bagi pemulihan ekonomi nasional [2]. Hal ini terbukti pertama, dari tahun ke tahun sektor pariwisata berhasil menyumbangkan devisa yang tidak sedikit. Dalam tahun 2000-2001 devisa yang dihasilkan cukup tinggi 10,4 milyar. Untuk tahun-tahun ke depan sektor pariwisata diperkirakan akan tetap memberikan sumbangan devisa yang besar bagi negara yaitu sebesar $\$ 22,70$ milyar. Kedua, pengeluaran belanja wisatawan, baik wisatawan mancanegara (wisman) maupun wisatawan nusantara (wisnus) terbukti mampu mengangkat perekonomian nasional, khususnya ekonomi kerakyatan tahun 2000, pengeluaran wisman dan wisnus diperkirakan mencapai angka Rp 90 triliun.

Pengembangan objek dan daya tarik wisata tersebut apabila di padukan dengan inovasi dalam pengembangan usaha jasa serta sarana pariwisata, seperti biro perjalanan, jasa konvensi, penyediaan akomodasi dan penyediaan transporttasi wisata akan berfungsi di samping meningkatkan daya tarik bagi 
berkembangnya jumlah wisatawan juga mendukung pengembangan objek dan daya tarik wisata baru.

Menghadapi kenyataan tersebut di atas, maka harus mulai menjalankan strategi pemasaran yang baik serta diikuti perbaikan kualitas dari sisi atraksi wisata dan aksesibilitas, kemudian meningkatkan semangat collective learning ini perlu di mulai dari tingkatan makro (pemerintah) sebagai inisitiator, change creator (Kotler, 2000), maupun fasilitator (Poter, 1995) hingga tataran mikro (pelaku bisnis) [3].

\section{Masalah Penelitian}

Berdasarkan judul peneliti yang di angkat yaitu: pengaruh daya tarik wisata dan aksesibilitas terhadap tingkat kunjungan wisata ke desa Boti, Kabupaten Timor Tengah Selatan. Maka dibuatlah hirarky permasalahan seperti yang di gambarkan dibawah ini:

\section{TINGKAT KUNJUNGAN WISATAWAN}

Wisata Alam

Wisata Budaya

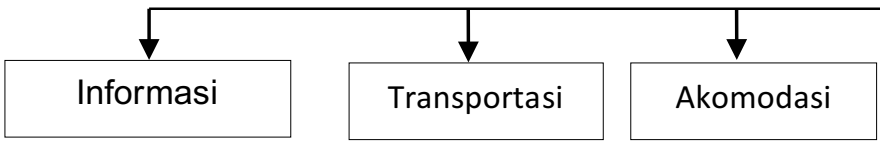

Aksesibilitas

Gambar 1.1 Problem Tree Masalah Penelitian (Sumber : inskeep (1991); Mill (2000)

Berdasarkan uraikan identifikasi masalah diatas maka dapat dirumuskan masalah penelitian sebagai berikut :

1. Apakah daya tarik wisata mempengaruhi kunjungan wisata ke desa boti?

2. Apakah aksesibilitas mempengaruhi kunjungan wisata ke desa boti?

\section{Tujuan Penelitian}

Sejalan dengan masalah penelitian diatas, maka selanjutnya dapat dibuat tujuan penelitian sebagai berikut :

1. Untuk mengetahui dan menganalisis pengaruh daya tarik wisata terhadap tingkat kunjungan wisata ke desa Boti.

2. Untuk mengetahui dan menganalisis pengaruh aksesibilitas terhadap tingkat kunjungan wisata ke desa boti.

\section{Manfaat Penelitian}

Adapun manfaat dari penelitian ini adalah sebagai berikut :

1. Hasil penelitian ini diharapkan dapat menajadi bahan pertimbangan bagi pemerintah Kabupaten Timor Tengah Selatan untuk memperhatikan aksesibilitas baik di Desa Boti maupun di objek-objek wisata lain di Kabupaten Timor Tengah Selatan.

2. Bagi Dinas Pariwisata Kabupaten Timor Tengah Selatan, kajian ini diharapkan menjadi pedoman untuk bisa mengemas potensi daya tarik wisata yang ada di TTS dengan baik.

3. Dapat menjadi referensi bagi penelitian selanjutnya.

\section{Keterbatasan Penelitian}

Infrastruktur jalan yang buruk menuju desa Boti membuat perjalan ke tempat tersebut sedikit terhambat dan penggunaan bahasa setempat menjadi keterbatasan dalam penelitian di Desa Boti, Kecamatan Kie, Kabupaten Timor Tengah Selatan.

\section{TINJAUAN PUSTAKA}

\section{Daya Tarik Wisata}

Menurut Cooper dkk (1995: 81) mengemukakan bahwa terdapat 4 (empat) komponen yang harus dimiliki oleh sebuah objek wisata [4], yaitu:

1. Atraksi (Attraction), seperti alam yang menarik, kebudayaan daerah yang menawan dan seni pertunjukan. 
2. Aksesibitas (accessibilities) seperti transportasi lokal dan adanya terminal.

3. Amenitas atau fasilitas (amenities) seperti tersedianya akomodasi, rumah makan, dan agen perjalanan.

4. Ancillary services yaitu organisasi kepariwisataan yang dibutuhkan untuk pelayanan wisata seperti destination marketing management organization, conventional and visitor bureau.

Undang-undang No. 10 Tahun 2009 menguraikan objek dan daya tarik wisata sebagai segala sesuatu yang menjadi sasaran wisata. Objek dan daya tarik wisata yang dimaksud adalah:

a. Daya tarik wisata adalah segala sesuatu yang memiliki keunikan, keindahan, dan nilai yang berupa keanekaragaman kekayaan alam, budaya, dan hasil buatan manusia yang menjadi sasaran atau tujuan kunjungan wisatawan.

b. Daerah tujuan pariwisata yang selanjutnya disebut Distinasi Pariwisata adalah kawasan geografis yang berada dalam satu atau lebih wilayah administratif yang didalamnya terdapat daya tarik wisata, fasilitas umum, fasilitas pariwisata, asesibilitas, serta masyarakat yang saling terkait dan melengkapi terwujudnya kepariwisataan.

\section{Aksesibilitas}

Mill (2000) mengatakan "accessibilities of the tourist destination, yaitu semua yang dapat memberi kemudahan kepada wisatawan untuk datang berkunjung pada suatu daerah tujuan wisata (DTW) [5]. Hal senada juga diungkapkan Suwantoro (2000 : 56) bahwa aksesibilitas adalah merupakan salah satu aspek penting yang mendukung pengembangan pariwisata, karena menyangkut pengembangan lintas sektoral [6]. Kemudian Soekadijo (2003 : 107108), mengatakan persyaratan aksesibilitas terdiri dari akses informasi dimana fasilitas harus mudah ditemukan dan mudah dicapai, harus memiliki akses kondisi jalan yang dapat dilalui dan sampai ke tempat objek wisata serta harus ada akhir tempat suatu perjalanan [7]. Oleh karena itu harus selalu ada: (1). Akses informasi.(2). Akses kondisi jalan menuju objek wisata. (3). Terminal, setidak-tidaknya tempat parkir. Untuk memenuhi tuntutan tersebut, pengusahaan pariwisata harus memilih dan menerapkan solusi yang tepat, serta memikirkan upaya untuk memperhatikan kepentingan pengunjung supaya dapat menciptakan tingka pengunjung yang tinggi, sehingga pada gilirannya akan memberikan pemasukan yang baik terhadap objek wisata.

\section{Kunjungan}

Saat ini pengunjung sangatlah berpengaruh terhadap suatu bisnis dalam pencapaian tujuan baik jangka pendek maupun jangka panjang. Suatu bisnis yang menciptakan suatu manfaat terhadap pelanggan diharapkan akan menghasilkan kinerja yang lebih baik. Menurut Zeithaml (2000:87), pengunjung bisa diidentifikasikan ke dalam empat arti yang berbeda yaitu: (1) harga murah, (2) apa yang diingkingkan produk, (3) kualitas yang diterima konsumen dan apa yang telah ia bayarkan, dan (4) apa yang konsumen dapatkan sebagai imbalan atas apa yang telah mereka berikan [8].

\section{Kerangka Berpikir}

Guna untuk memudahkan penelitian mengenai pengaruh atraksi wisata dan asesibilitas terhadap tingkat kunjungan wisata ke desa boti, maka disusunlah kerangka berpikir sebagai berikut :
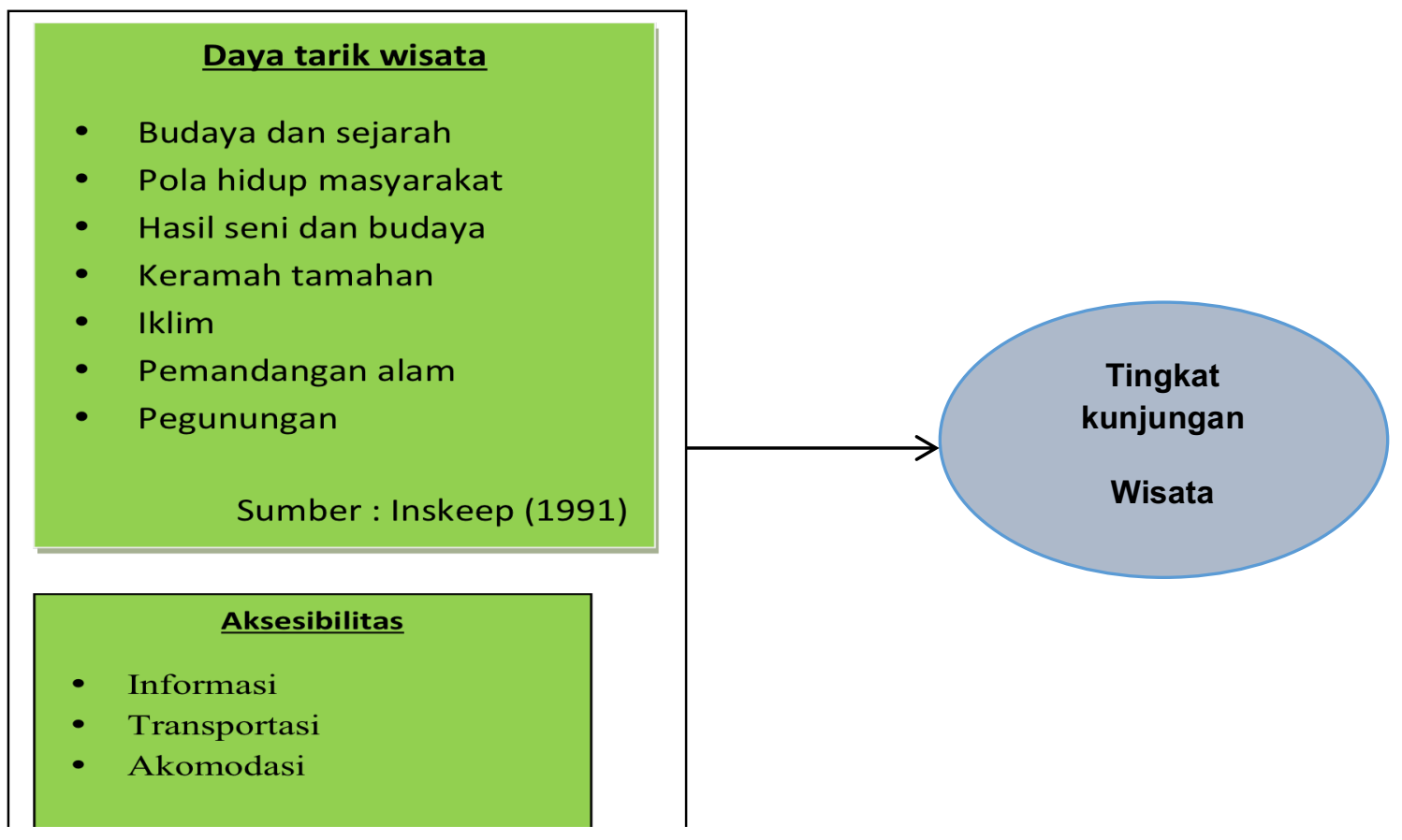


\section{METODELOGI PENELITIAN}

\subsection{Rancangan Peneltian Objek Penelitian}

Objek penelitian ini adalah Suku BOTI di Desa Boti Kecamatan Kie yang terletak di kabupaten Timor Tengah Selatan Provinsi Nusa Tenggara Timur.

\section{Metode penelitian \\ Ada beberapa metode yang dapat digunakan dalam penelitian bidang}

kepariwisataan, untuk aplikasi dalam penelitian ditentukan dengan kepentingan dan kondisi dari masing-masing penelitian tersebut. Tipe penelitian yang digunakan dalam penelitian pengaruh atraksi wisata dan asesibilitas ke desa Boti ini adalah penelitian deskriptif dengan pendekatan kualitatif.

\section{Variabel Penelitian}

Dalam penelitian yang akan menjadi variabel terdiri dari faktor daya tarik wisata, aksesibilitas dan tingkat pengunjung untuk lebih jelasnya dapat dilihat pada table berikut :

Tabel 3.1

Variabel Penelitian

\begin{tabular}{|c|c|c|l|}
\hline No & Variabel & Subvariabel & \multicolumn{1}{c|}{ Indikator } \\
\hline \multirow{4}{*}{1.} & $\begin{array}{c}\text { Daya tarik wisata } \\
\text { Sumber:Inskeep } \\
(1991)\end{array}$ & $\begin{array}{l}\text { Wisata } \\
\text { Budaya }\end{array}$ & $\begin{array}{l}\text { Arkeologi } \\
\text { Budaya dan Sejarah } \\
\text { Pola hidup masyarakat } \\
\text { Hasil Seni dan Budaya } \\
\text { Keramah tamahan penduduk lokal }\end{array}$ \\
\cline { 3 - 4 } & Wisata Alam & $\begin{array}{l}\text { Iklim } \\
\text { Pemandangan alam } \\
\text { Hutan }\end{array}$ \\
\hline \multirow{2}{*}{2.} & $\begin{array}{c}\text { Aksesibilitas } \\
\text { Sumber: Mill (2000) }\end{array}$ & Fasilitas & $\begin{array}{l}\text { Informasi } \\
\text { Transportasi } \\
\text { Akomodasi }\end{array}$ \\
\hline \multirow{2}{*}{3.} & Tingkat Kunjungan & & Frekuensi kunjungan wisata \\
\hline
\end{tabular}

\section{Prosedur Penarikan Sampel}

Prosedur penarikan contoh dapat digolongkan dalam probability sampling. Penarikan contoh dengan contoh prosedur probability sampling membuat peluang seseorang untuk menjadi responden telah di ketahui. Populasi dalam penelitian ini adalaah keseluruhan sampel yang di ambil dengan metode purposive sampling untuk mengelompokan sampel sesuai dengan tujuan penelitian. Sampel meliputi kepala desa, kepala suku, dinas pariwisata dan beberapa pengunjung.

\subsection{Devinisi Operasional Variabel}

Adapun definisi operasional variabel dalam penelitian ini adalah:

\section{Daya Tarik Wisata}

a. Wisata alam

Iklim, Pemandangan alam, pegunungan yang ada di daerah wisata dan menjadi menjadi daya tarik bagi setiap wisatawan yang berkunjung. b. Wisata budaya/buatan manusia

Arkeologi, budaya dan sejarah, pola hidup masyarakat, hasil seni dan budaya serta keramahtamahan penduduk lokal yang ada di daerah kunjungan wisata dan yang menjadi daya tarik untuk wisatawan mengunjunginya.

\section{Aksesibilitas}

a. Informasi

Dari mana informasi itu didapat sehingga wisatawan mengetahui dan berkunjung ke objek wisata desa Boti.

b. Transportasi

Adanya transportasi serta akses jalan yang memadai dan membawa wisatawan berkunjung ke desa Boti.

c. Akomodasi

Adanya akomodasi yang tersedia di objek wisata desa Boti dalam menjawab kebutuhan wisatawan.

\section{Tingkat kunjungan}

a. Frekuensi kunjungan wisata 
Berapa kali wisatawan melakukan kunjungan ke desa Boti.

\subsection{Teknik Pengumpulan Data}

Pengumpulan data, khususnya data primer dilakukan dengan teknik wawancara dan observasi secara simultan. Wawancara ditujukan pada responden yang diyakini sebagai individu yang paham akan situasi desa boti. Sehingga apa yang dilakukan oleh responden dapat diyakini sebagai kebenaran dan dapat dipercaya.

Untuk menjaga validitas data wawancara diprioritaskan pada beberapa perangkat kepala desa, kepala suku, dan pengelola daya tarik wisata desa Boti dengan mempertimbangkan beberapa aspek dari profesi dan tingkat pendidikan selain wawancara pengumpulan data juga dilakukan dengan observasi.

\subsection{Metode Analisis Data}

Penelitian pengembangan destinasi wisata di desa Boti ini menggunakan analisis deskriptif.Gibson (1993) dalam Micthell, setiawan dan Rahmi (2000), menyarankan bahwa seperangkat prinsip dapat diidentifikasikan untuk merancang analisis dampak [9]. Meskipun setiap rancangan tidak mungkin sempurna untuk semua situasi. Untuk lebih jelasnya sebagai berikut :

\section{Analisis Descriptif Kualitatif}

Analisis deskriptif kualitatif adalah proses mengatur, mengurutkan, mengelompokan, memberi kode, mengkategorikan, mengartikan, dan menginterpretasikan / menafsirkan data dan informasi kualitatif tanpa ada hitunghitungnya. Proses ini berusaha mendeskripsikan, menggambarkan fenomena atau hubungan antar fenomena yang diteliti dengan sistematis, factual dan akurat.

\section{HASIL DAN PEMBAHASAN}

\section{Gambaran Lokasi Penelitian}

Desa boti merupakan nama dari salah satu desa tradisional yang berada di Kecamatan Ki'e Kabupaten Timor Tengah Selatan, Propinsi Nusa Tenggara Timur. Desa boti terletak di sebelah timut Kota Soe dan bagian selatan propinsi Nusa Tenggara Timur dengan luas wialayah 16.500 ha.

\section{Pengaruh Daya Tarik Wisata terhadap tingkat kunjungan wisata}

Untuk mengetahui apakah daya tarik wisata mempengaruhi tingkat kunjungan wisata ke desa Boti, maka peneliti melakukan wawancara dengan Kepala Bidang Destinasi dan Pemasaran Pariwisata Kabupaten Timor Tengah Selatan, Kepala Desa Boti serta Kelapa Suku Boti.

Menurut Kepala Bidang Destinasi dan Pemasaran Pariwisita Kabupaten Timor Tengah Selatan, Bapak Don da Costa, Sos, M.Par mengatakan :

"Desa Boti merupakan salah satu aset pariwisata terbaik Kabupaten Timor Tengah Selatan yang mana masyarakatnya masih mempertahankan adat dan tradisi orang Timor. Perlu diketahui bahwa objek wisata desa Boti dikelolah sendiri oleh warga suku Boti dalam dan mereka tidak menerima interfensi dari siapapun. Dengan keterbelakangan pendidikan yang mereka miliki untuk mengelolah objek wisata dan dengan kemajuan teknologi saat ini, ditakutkan tradisi yang mereka anut bisa hilang kemudian hari karena bisa kita lihat sekarang beberapa rumah sudah menggunakan seng sebagai atap rumah mereka dan lantai rumah mereka sudah memakai campuran semen".

Lebih lanjut Kabid Destinasi dan Pemasaran Pariwisata Kabupaten Timor Tengah Selatan ini menyampaikan bahwa :

"Biasanya wisatawan yang datang ke objek wisata Desa Boti adalah wisatawan dari mancanegara dan tujuan mereka adalah ingin melihat seperti apa keseharian warga desa Boti Dalam dan atraksi-atraksi budaya serta ritual adat yang ada di desa Boti ini, dan yang menjadi kekuatan dari objek wisata ini adalah upacara adat dan keseharian mereka. hal itu yang membuat banyak wisatawan dari luar negeri datang berkunjung.

Untuk daya tarik wisata alam, memang bukan menjadi prioritas utama para pengunjung yang datang ke tempat ini. tetapi bisa kita lihat pemandangan alam di desa Boti sangat bagus dengan bukit-bukit yang tinggi serta hutannya yang masih terjaga menjadi daya tarik bagi wisatawan. Perlu di ketahui bahwa adat suku boti menentang warganya untuk tidak boleh menebang pohon sembarangan".

Pada kesempatan yang lain, Kepala Desa Boti Bapak Bernadus Neoloka mengatakan bahwa :

"Budaya orang Boti (khususnya suku Boti Dalam) sangat menarik dan itu yang membuat banyak orang mau berkunjung ke Desa ini. keramahan warga desa Boti menjadi salah satu daya tarik tersendiri, 
pada umumnya orang Boti sangat menghargai tamu dan tamu adalah raja bagi mereka. Kalau pengunjung ingin mengetahui kehidupan warga Boti seperti apa, biasanya pengunjung menginap beberapa hari di kampung ini. Biasanya orang yang datang ke sonaf (kawasan Suku Boti Dalam), tujuannya untuk melihat seperti apa kehidupan masyarakat suku boti dan tradisi-tradisi yang ada di tempat ini".

Untuk menguatkan hasil wawancara dan kesimpulan dari peneliti di atas, maka peneliti menyebarkan kuesioner untuk pengunjung yang datang sebagai tolak ukur dalam menilai apakah daya tarik wisata budaya mempengaruhi tingkat kunjungan wisatawan ke objek wisata desa boti. Peneliti menyebarkan kuesioner ini kepada 20 responden sebagai bahan untuk menjadi tolak ukur.

Berikut pendapat wisatawan tentang daya tarik wisata budaya suku Boti, pendapat wisatwan di bagi menjadi 4 indikator di antaranya: kebudayaan, pola hidup masyarakat, hasil seni dan budaya serta keramahan warga suku Boti. Lebih jelasnya di paparkan dalam paragraf-paragraf berikut.

20 wisatawan yang berkunjung dan mempunyai tujuan/motivasi untuk melihat kebudayaan dan keseharian warga boti sebanyak 80 orang $90 \%$, dan 2 orang $10 \%$ mempunyai tujuan untuk melakukan penelitian.

Untuk indikator kebudayaan sebanyak 19 orang $95 \%$ berpendapat sangat baik, dan 1 orang 5\% menyatakan lebih baik. Pola hidup masyarakat dari 20 responden 3 orang 15\% berpendapat baik, 15 orang $75 \%$ menyatakan lebih baik dan 2 orang $10 \%$ menyatakan sangat baik. Indikator hasil seni dan budaya 9 orang $45 \%$ berpendapat baik, 6 orang $30 \%$ menilai sangat baik dan 5 orang $25 \%$ menyatakan lebih baik. Indikator keramahan warga boti dari 20 responden 17 orang $85 \%$ berpendapat sangat baik dan 3 orang $15 \%$ berpendapat baik.

Hasil ini menyatakan bahwa daya tarik wisata budaya di desa Boti sangat baik dan menjadi daya tarik utama wisatawan untuk berkunjung ke Desa Boti.

Sedangkan untuk daya tarik wisata alam dari hasil pengumpulan lembar kuesioner untuk 20 responden, 12 orang $60 \%$ responden berpendapat bahwa iklim di desa Boti baik, 2 orang $10 \%$ menyatakan sangat baik, 4 orang $20 \%$ berpendapat lebih baik, dan 2 orang $10 \%$ menyatakan buruk. Untuk indikator pemandangan alam yang ada di desa Boti, dari 20 responden 15 orang $75 \%$ berpendapat bahwa sangat baik, 2 orang 10\% berpendapat baik dan 3 orang $15 \%$ berpendapat bahwa pemandangan alam di desa boti sangat buruk.
Untuk pendapat responden tentang pegunungan di desa boti 9 orang $45 \%$ responden menyatakan baik, 3 orang $15 \%$ menyatakan lebih baik, 5 orang $25 \%$ menyatakan sangat baik dan 3 orang $15 \%$ menyatakan buruk.

\section{Pengaruh Aksesibilitas terhadap tingkat kunjungan wisata}

Untuk mengetahui apakah aksesibilitas berpengaruh terhadap tingkat kunjungan wisata, maka peneliti melakukan wawancara dan juga melakukan penyebaran kuesioner. Berikut hasil wawancara yang peneliti lakukan.

Menurut Kepala Bidang Destinasi dan Pemasaran Pariwisita Kabupaten Timor Tengah Selatan, Bapak Don da Costa, Sos, M.Par mengatakan bahwa:

"pada umumnya akses jalan dan transportasi untuk objek wisata di Kabupaten Timor Tengah Selatan tidak mendukung begitu pula di desa boti, sampai saat ini tidak ada kendaraan umum yang sampai ke objek wisata desa boti. Jika kita ingin berkunjung ke desa boti, kita harus menyewa kendaraan umum atau membawa kendaraan pribadi. Tetapi sampai saat ini masalah akses jalan dan transportasi tidak menjadi masalah yang besar untuk menghambat niat wisatawan berkunjung ke desa wisata boti. Untuk sarana akomodasinya, di desa boti ada homestay yang bisa pengunjung gunakan bila ingin meninap dan juga pengunjung bisa membeli beberapa souvenir yang di jual oleh masyarakat setempat seperti tenun ikat dan hasil kerajinan lainnya".

Untuk masalah aksesibilitas di desa Boti menurut kepala Desa Boti, Bapak Bernadus Neolaka mengatakan bahwa :

"kondisi jalan di desa ini masih jauh dari kata baik, memang banyak wisatawan yang berkunjung ke desa ini tetapi kalau jika musim hujan tiba kami di tempat ini tidak bisa bepergian kemana-mana dan wisatawan tidak bisa datang. Ada 2 jalur menuju tempat ini, yakni jalur timur (dari oinlasi) dan jalur barat (dari oenai) tetapi pada musim hujan di jalur timur terjadi banjir dan tidak bisa kita sebrangi. Sedangkan jalur barat jalannya sangat licin dan banyak jalan berbukit yang tidak bisa dilewati oleh kendaraan roda 4 maupun roda 2. Untuk sarana transportasi di sini memang tidak ada kendaraan umum selain ojek".

Hasil wawancara dari 2 sumber ini dan hasil pengamatan yang peneliti dapatkan 
bahwa, memang untuk kawasan wisata desa boti, sarana transportasi dan akses jalannya masih jauh dari kata baik.

Untuk mengetahui apakah aksesibilitas mempengaruhi tingkat kunjungan wisata ke desa boti maka peneliti melakukan sebaran kuesioner kepada wisatawan.

Berikut pendapat responden tentang pengaruh aksesibilitas terhadap tingkat kunjungan wisata. Dari 20 responden yang berkunjung ada 18 orang $90 \%$ berpendapat bahwa transportasi di desa Boti buruk, 1 orang $5 \%$ berpendapat sangat buruk, 1 orang $5 \%$ berpendapat baik. Untuk akomodasi di desa boti 16 orang $80 \%$ berpendapat baik, dan 4 orang $20 \%$ berpendapat sangat baik.

Sistem informasi yang di dapat dari responden sesuai dengan lembar kuesioner yang di jawab, 12 orang responden berpendapat bahwa mereka mendapatkan informasi tentang desa Boti dari media elektronik, 5 orang menyatakan bahwa mereka mendapat informasi dari teman-teman yang sudah lebih dulu berkunjung ke desa boti dan ada 3 responden yang menyatakan bahwa informasi yang mereka dapat tentang desa boti yaitu dari media masa.

Dari tingkat kunjungan wisatawan sesuai dengan data pengisian kuesioner, peneliti mendapatkan data bahwa ada 12 responden yang baru pertama kali berkunjung ke desa boti, sedangkan 6 responden menyatakan bahwa mereka sudah 2 kali berkunjung ke desa boti dan 2 responden lainnya menyatakan mereka berkunjung sudah lebih dari 3 kali dan dari 20 responden yang telah mengisi lembar kuesioner meliki tujuan dan motivasi yang berbeda-beda pada saat berkunjung ke Desa Boti, diantaranya 18 responden menyatakan bahwa tujuan mereka ke desa boti untuk melihat keseharian dan kebudayaan yang di miliki oleh warga suku boti, sedangkan 2 responden lainnya menyatakan bahwa tujuan mereka yaitu untuk melakukan penelitian.

Hasil pengisian lembar kuesioner yang responden lakukan, pendapat responden tentang aksesibilitas ke desa boti memang masih menjaadi masalah utama. Tetapi responden berpendapat bahwa hal itu tidak menghambat niat mereka untuk berkunjung ke desa boti, bahkan ada beberapa responden yang menyatakan bahwa dengan kondisi jalan seperti ini menjadi suatu daya tarik bagi mereka.

\section{PENUTUP}

\section{Kesimpulan}

Berdasarkan pada hasil pembahasan pada bab sebelumnya, dapat disimpulkan bahwa pengaruh daya tarik wisata dan aksesibilitas terhadap tingkat kunjungan wisata ke Boti sebagai berikut:

1. Pengaruh daya tarik wisata budaya terhadap tingkat kunjungan wisata adalah pengaruh dari kebudayaan dengan hasil presentase $95 \%$ berpendapat sangat baik, yang kedua yaitu pengaruh keramahtamahan dengan hasil $85 \%$ dengan hasil yang di dapatkan pengaruh kebudayaan dan keramahtamahan yang di miliki oleh objek wisata desa Boti mampu meningkatkan jumlah kunjungan wisata serta mampu menarik motivasi wisatawan untuk melakukan kunjungan ke tempat ini. Selain itu pengaruh daya tarik wisata alam terhadap tingkat kunjungan wisata yaitu pengaruh pemandangan alam desa boti dengan hasil presentase $75 \%$ yang berpendapat sangat baik, dan kedua yang menjadi pengaruh daya tarik wisata terhadap tingkat kunjungan yaitu pengaruh iklim dengan presentase $60 \%$ yang berpendapat baik.

2. Pengaruh aksesibilitas terhadap tingkat kunjungan wisata ke desa Boti yaitu pengaruh transportasi dengan presenatase $90 \%$ berpendapat buruk, untuk akomodasi bisa dikatakan baik, dimana dengan presentase $80 \%$ responden berpendapat baik.

\section{Saran}

1. Dalam pengembangan objek wisata Desa Boti harus ada kerja sama yang baik, antara Dinas Pariwisata Kab. Timor Tengah Selatan dan warga Suku Boti.

2. Harus ada aturan-aturan yang berlaku khusus untuk kawasan "Suku Boti Dalam", sehingga tidak ada pengaruh teknologi yang msauk dan mengganggu kehidupan dan keaslian Suku Boti.

3. Jalan desa Boti harus di tata dengan baik, walaupun tidak di aspal setidaknya di beri tumpukan sertu agar jalannya tidak licin pada musim hujan.

\section{DAFTAR PUSTAKA}

Cooper, Donald R and Shindker, Pamela S (2003 Bussiness Reaserch Method. Mc Grow Hill. New York).

Gamal Suwantoro, 2000, Dasar-dasar Pariwisata, Penerbit Andi. Yogyakarta

Hery Susanto, Darmaji, dan Dwi Agus Susilo, 2003, Otonomi Daerah Dan Kompetensi Lokal: Pikiran Serta Konsepsi Syaukari 
HR. Penerbit Milenium Publisher PT. Dyatama Milenia. Jakarta

Kotler, Philips, Marketing Managemen.

Analysis, Planning, Implementation and Control, Milenium Editions, Prentice Hall International, Inc A Divisions of Simon \& Scuster, Englewood Cliffs,Nj07632,2001

Mill, Robert Cristie, 2000, Tourism, The International Business: Terjemahan Tri Budi Satrio, Penerbit Raja Grafindo. Jakarta

Naisbitt, Jhon., 1994, Global Paradox, alih bahasa Budijanto, Penerbit Binapura Aksara, Jakarta Indonesia.

Soekadijo, R.G. 2003, Anatomi Pariwisata Memahami Pariwisata Sebagai Systemic Linkage. Jakarta: PT. Gramedia Pustaka Utama

Zeithaml, Valeria A. And Bitner. (2000). Service Marketing $2^{\text {nd }}$ edition : Integrating Customer Focus. New York.McGraw-Hill Inc 